\title{
INTRODUCTION: FROM CONCEPTUAL DEBATES TO PRACTICAL APPLICATIONS
}

\author{
Sergey Troitskiy \\ Senior Research Fellow \\ Herzen State Pedagogical University of Russia \\ sergtroy@yandex.ru
}

Leena Kurvet-Käosaar

Associate Professor of Cultural Theory

University of Tartu, Estonia

leena.kurvet-kaosaar@ut.ee

Liisi Laineste

Senior Research Fellow

Estonian Literary Museum, Estonia

liisi.laineste@folklore.ee

\begin{abstract}
Bringing into focus the ways of how to approach trauma instead of defining the object of research is becoming increasingly important. This also indicates that the range of approaches to trauma that informs cultural inquiry is widening, and is moving away from one singular paradigm posited as universal. Trauma scholars have demonstrated, on the one hand, the importance of particular experiences, specific cases, individual features of experiencing, remembering, and narrating trauma. On the other hand, they have pointed out the impact of cultural "scripts" shaped by broader cultural understandings and social and cultural regulations and preferences that shape the possibilities of the representation of traumatic experience. This special issue seeks to recognize and negotiate the individual and collective dimensions of trauma as well as their interwovenness, with a focus on the (post)-Soviet and Eastern European experience. It does so by addressing the generalizing theoretical models as well as the practical, material, and experimental aspects of trauma. Thus, it seeks to disentangle and clarify the links between the collective and the individual, the theoretical and the practical, and finally, the universal and the specific, the global and the local.
\end{abstract}

Keywords: collective trauma, cultural trauma, Eastern Europe, individual trauma, post-Soviet, trauma studies

Originally referring to physical injury as psychological damage affecting selfperception and capacity for normal functioning on individual and collective 
level, the concept of trauma has gained prominence in a wide variety of social and cultural practices, discursive constellations, and areas of expertise. In the most general sense, trauma refers to lasting psychological damage, manifesting itself importantly via a disruption of memory and identity and occurring as a result of (often) violent, life-threatening experience causing severe distress to individuals or communities (Davis \& Meretoja 2020: 1; Luckhurst 2008: 79). To a large extent, trauma theory has been developed on the basis of the Holocaust. Other large-scale historical events considered within this framework from a variety of disciplinary perspectives include, for example, the Armenian, Rwandan, and Cambodian genocides, the Vietnam War, 9/11, the Gulag as well as mechanisms of structural violence relating to, for example, colonialism and racism. While the question of hierarchies and preferences of historical events included within the trauma paradigm has received quite a bit of critical attention (see, e.g., Bennett \& Kennedy 2003: 4-11; Craps \& Bond 2020: 104-112; Schaffer \& Smith 2004: 20-22), it is also important to draw attention to those contexts of traumatic experience that relate to common everyday life, involving, for instance, domestic violence, sexual abuse and social marginalization, which are closely related to and depend on social and political regulations and cultural discourses.

In the field of cultural inquiry and cultural theory, the impact of the work of Cathy Caruth (1995a; 1995b; 1996) as well as that of Dori Laub and Shoshana Felman (1992) and Dominick LaCapra (2000), which has been informed by psychoanalysis, poststructuralism, and deconstruction, has been seminal. The central defining feature of that paradigm is "pathology of ... the structure of ... experience" - the failure of the event or condition causing trauma to be integrated into memory (Caruth 1995a: 4). Trauma is believed to remain "largely inaccessible to conscious recall and control" and to manifest itself in the form of "often delayed, and uncontrolled repetitive occurrence of hallucinations and other intrusive phenomena" that merits the status of reexperience rather than memory (Caruth 1995b: 151; 1995a: 11) and results in a collapse of the distinction between the past and the present. In the Western world, a psychoanalytically informed conceptualization of trauma understood as having a shattering effect on the self, has greatly influenced the ways in which trauma has been represented and interpreted with a longstanding contradiction relating to the possibility and necessity of verbal and narrative representation of trauma.

Poststructuralist influence on theorizing trauma that underlines the paradigm developed by Caruth (1995a, 1995b), as well as Felman and Laub (1992), posits trauma as something that, by its very essence, cannot be or should not be represented in language or narratively mediated. The influence of such perspective can be seen in stylistic and narrative preferences of modernist and 
postmodernist (literary) trauma narratives or narratives that have been considered as such by trauma scholars because of the presence of certain stylistic features. These include, for instance, narrative fragmentation, inconsistencies, repetitions, disrupted temporalities, gaps, and silences (see Meretoja 2020: 26; also Whitehead 2004; Pederson 2018). As Hanna Meretoja has argued, the fundamental distrust of post-structurally oriented inquiries into trauma stems from a more general view of poststructuralism toward explanation and understanding as violent appropriation by its very essence (Meretoja 2020: 29). As the range of approaches to trauma that informs cultural inquiry is widening, importantly also including cognitive and neuroscientific research (see, e.g., Jensen 2019; Pederson 2020: 220-229), the dissociative model proposed by Caruth is no longer viewed as the only possible response to trauma. Although hugely influential, the exclusivity of such a paradigm has been challenged by innumerable renderings of traumatic experience in all kinds of narrative formats as well as the work of many trauma scholars who engage with different theoretical and critical paradigms, demonstrating the importance of narrative mediation of traumatic experience for a number of purposes, from coping and healing to bringing about changes in cultural perceptions and social and legal regulations (see, e.g., Balaev 2014; Jensen 2019; Douglas 2010). Approaching the possibilities of narrative representation of traumatic experience from a somewhat different angle, several trauma scholars have also demonstrated the impact of cultural "scripts" influenced by broader cultural understandings and social and cultural regulations and preferences that shape the possibilities of the representation of traumatic experience and can have both an empowering and limiting or even cancelling effect (Douglas 2010; Gilmore 2017: 85-117).

A genealogical approach to the conceptual frameworks of trauma (see in particular Luckhurst 2008; also Leys 2000; Sütterlin 2019; Kansteiner 2004) extends the trajectories of inquiry beyond a singular theoretical frame based on a few central limit events (most importantly the Holocaust) or developments (such as the inclusion of the posttraumatic stress disorder in the 1980 edition of the manual of the American Psychiatric Association) and a single paradigm based on a specific perspective of Freudian psychoanalysis. Nevertheless, the influence of Freud's ideas on the development of the conceptual framework of trauma is undebated though evaluation of his contribution and modes of engagement with it vary. In particular, his work focusing on the phenomenon of "shell-shock" - soldiers returning from World War I, who suffered from nervous disorders for which there was no direct physical cause - is considered to have partially laid the foundation of both the PTSD diagnosis and the most widely used therapy that seeks to integrate dissociated memory into a coherent, affectively engaged personal narrative (Herman 1992: 175). Trauma is viewed as 
a characteristic feature of modernity, related to changes in the way of life and stability of self-identity brought about by the modernization and industrialization of the (Western) societies starting with the end of the eighteenth century, accompanied by increasing urbanization during the nineteenth century. As Nicole Sütterlin argues, "the conditions for the emergence of trauma as a cultural syndrome ... [were generated] already in the late 1700s and early $1800 \mathrm{~s}$ ", featuring the emergence of a "modern subject that is inherently and necessarily vulnerable" (2020: 15). According to Roger Luckhurst, the contradictions of modernity are exemplified by ways of conceiving technological advances, simultaneously viewed as "the prosthetic extension of [the] will to mastery" and as "a violent assault on agency and self-determination" (2008: 20). More concretely, the emergence of the concept of trauma is related to the expansion of railroads in the second half of the nineteenth century and accompanying fatal railway accidents that soon became the subject of medical attention from the perspective of mental health as well as a legal subject of liability and eligibility for compensation (Luckhurst 2008: 21; Sütterlin 2020: 12-13). In The Trauma Question, Luckhurst outlines a genealogy of the concept or trauma that he envisions as an "exemplary conceptual knot" (an approach adopted from Bruno Latour) that seeks to "track the multi-disciplinary origin of trauma in the nineteenth century through industrialization and bureaucratization, law and psychology, military and government welfare policies ...[to] our current conjuncture ... knot[ing] these diverse and discontinuous elements together in the identity politics of the 1970s" (2008: 15).

As many scholars of trauma have argued, the centrality of trauma in the conceptualizations of culture and history does not rely primarily on its medical history (alone) but excessively in its status as "a category of social discourse of strongly moral significance" (Davis \& Meretoja 2020: 3; also Fassin \& Rechtman 2009: 284), foregrounding the responsibility of societies "toward their most vulnerable subjects" as well as the process of recollection and remembrance of historical events on national and international scale (Sütterlin 2020: 17). Though there is a relatively clear distinction, in particular on the theoretical level, between individual and collective (cultural) trauma, especially vis-à-vis the expanded scale of experience that can be viewed as traumatizing within a variety of contexts, neither the distinction nor the dynamics of its discursive authority may completely hold or could be conceived of by way of a "sliding scale" (Hodgkin \& Radstone 2003: 100). As a central category in dealing with suffering and injustice of the past on the individual and collective level, trauma has also been viewed as a conceptual framework, a clear-cut division between victims and perpetrators, with the former constituting a position assumed by discourses of cultural criticism. More recently, the focus has expanded to include 
the position of the perpetrator and to "attend critically and consciously both to issues of guilt and complicity" (Adams \& Vice 2013: 1-2). It is also important to consider that the availability of the position of the victim requires systems of recognition and support may not be (or may not have been) available in different socio-historical contexts, nor may the position of the victim, in particular in definitive sense - a trauma victim is all that one is - be desirable or ultimately helpful for overcoming traumatic experience.

The extensive spread of areas of application of the concept of trauma, in particular those in the popular public realm, has created a "trauma boom" that has also brought about the trivialization of trauma, its utilization in relation to "inconsequential, ultimately harmless nibbles of our daily lives" (Davis \& Meretoja 2020: 1). Trauma has also been discussed in terms of the domination of a "wound culture", which capitalizes, often via different modes of consumption, on the extensive public attention on and engagement with "suffering, states of injury and wound attachment" (Seltzer 1997: 4). The extensive circulation of trauma in contemporary (Western) culture attests to a vogue of consumption of trauma for pleasure as well as its circulation for profit, including academic one (Miller \& Tougaw 2002: 2; Yaeger 2002: 29) and it has been discussed in terms of trauma industry, marketing, and consumption and trauma aesthetic, visible, for instance, in memorial architecture (Craps \& Bond 2020: 3). Roger Luckhurst has also pointed out that traumatization, or as he formulates it, a perception of "woundedness", frequently emerges as the basis of collective identity on ethnic, national, and political level (2008: 2). Hence, according to him, "traumatic identity is commonly argued to be at the root of many national collective memories" (ibid.) to an extent that it is possible, as Andreas Huyssen has argued, to view the entire twentieth century within the context of historical trauma (2003: 8). Yet the "affective transmissibility of trauma" (Luckhurst 2008: 119), in particular the dynamics of the impact of an individual act of mediating traumatic experience on collective memory and identity, has also been viewed as contributing to community-building processes, believed to help to "repair the tears in the collective social fabric" (Miller \& Tougaw 2002: 2-3). A failure of societies to facilitate the mediation of traumatic experience either by narration or by different formats of commemoration and testimony creates the risk of perpetuation of "mechanisms of ... violence ... inherited from the past" (Davis \& Meretoja 2020: 1; see also Gilmore 2008: 367) and blocks out the possibility of healing from the wounds of the past which, if left unattended, can be transmitted from generation to generation, hindering normal healthy processes of identity construction on individual as well as communal level. Narratives of traumatic experience, often of self-representational nature, have contributed to "ways of coming to terms with and coping with traumatic 
experience on individual and collective level ... reassessment and revision of historical knowledge and cultural memory and the relationship between the private and the public and participating in social action concerning legislation and policymaking" (Kurvet-Käosaar 2020: 305).

While it would not be possible to make a comprehensive list of historical events that have been or are being viewed as traumatic, an extensive focus of the field on a limited number of "cataclysmic European and US historical events" (Traverso \& Broderick 2010: 3; see also Bennett \& Kennedy 2003: 1-15; Douglas \& Whitlock \& Stumm 2008: 1-8) as well as the Eurocentric nature of trauma theory itself (Craps \& Bond 2020: 106) has been a distinctive feature of inquiries into trauma for a long time. Scholars of global memory and those specializing on sociopolitical, historical, and cultural regions on the borderlines or outside the Western or Eurocentric realms have underlined the need for the development of a new trauma theory that would abandon the universalizing claims of psychoanalytically informed conceptual framework of trauma and would be able to cater for cultural specificities of understanding, processing, and mediating traumatic experience as well as the processes of coping with it on a wider global scale (Schaffer \& Smith 2004: 20-22; Bennett \& Kennedy 2003: 4-11). And yet, as Jehanne M. Gheith states, with respect to historical memory concerning the twentieth century in general and trauma in particular, "the Gulag in which some 10-20 million people died and whose effects continue to be far-reaching ... barely inhabits ... the Western imagination" (2007: 159). This can be attributed to a number of reasons, such as, for example, lack of international dialogue on the subject, lack of public trials concerning the Gulag with a respective lack of public accountability, the extensive duration of the Gulag, and its being "of a substantially different order" from the Holocaust as the "real limit event" (Gheith 2007: 160; see also Tumarkin 2011: 1047). Such a view is supported by other scholars working on Stalinist repressions and the Gulag who, similarly to Gheith (2007: 159-175), emphasize the need for different discourses and methodologies that would cater for the specificity of traumatic experience in the case of Soviet totalitarianism (see, e.g., Merridale 2010: 379, 380-381; Tumarkin 2011: 1053-1055; Paperno 2009). The critical responses elaborated in these studies vary. Some scholars refrain from the use of the traditional conceptual frame of trauma (Paperno 2009: 2) and argue that posttraumatic stress disorder (PTSD) as a medical diagnosis is irrelevant in the Soviet case due to the cultural specificity of reactions to suffering (Merridale 2010: 379-380). Others propose alternative conceptualizations of trauma manifestation and of ways of dealing with traumatic experience. For example, Gheith (2007: 161) outlines the importance of "ways of working through a loss that do not involve verbal recovery or where verbal accounts are a secondary or tertiary 
factor", and Maria Tumarkin (2011: 1053) argues for the need of inquiry into "the long-term affective states purposefully and masterfully engendered by totalitarianism in its particular historical forms".

\section{PRAGMATICS OF TRAUMA NARRATIVES}

The angle provided by the discipline of philosophy within trauma studies provides a macro-level picture that strives to lay down universal models and rules according to which a trauma is experienced in society. This in turn needs to be balanced out with an analysis of specific cases, the particular features of the micro-level analysis, which can be provided by cultural or literary studies. Reasoning on the psychological macro-level is useful when we realize that a near-death experience can also be felt on a social level, through all the "bodies" in which a person resides. Experiencing the reality of the death of a body that is included in the political or cultural space is a traumatic experience that requires different work strategies than that of the individual trauma. ${ }^{1}$ Foucault's concern for the self as a concern for the Other is transformed here into a kind of experience of the reality of the death of the Other. The experience of the disintegration of the Other's body is experienced as one's own death, which is expressed in the loss of subjectivity, but not only psychological. And if hypertrophied subjectivity - expressed, for example, in the survivor's guilt and the desire to disappear - is a psychotherapeutic problem and a manifestation of an individual trauma, then the annihilation of subjectivity through shame is a manifestation of the political or cultural body and a problem that dovetails the field of ethics, culture, law, and politics. Thus, human rights, witness testimony, identification of the criminal - all these legal practices are directly related to the manifestation of the political body by the subject. This, in turn, tempts a look at the given norms and rules of trauma experience in society as something that can be tentatively called a "descriptive bolvanka" (from the word bolvan 'dummy').

Both individual and cultural traumas are embedded inside the canvas of everyday life by the narrative practices of "activating someone else's trauma" (Oushakine 2009). In both cases the first way of protecting the traumatized person is lapses in memory. This mechanism works automatically in individual trauma (Halligan \& Clark \& Ehlers 2002). PTSD therapy allows to overcome memory loss and to lead traumatic experiences on the level of narration. However, memory often offers activating someone else's trauma; talking about, describing, and overcoming someone else's experience (Jelinek et al. 2009). Perhaps 
this is due to the fact that a localization scenario has been already formed in someone else's experience by their describing and ordering rhetorical clichés.

Similar mechanisms are relevant for a cultural trauma (Cwalina \& Falkowski 2008): "Death is like a start and a beginning. Grief is like a unifying principle. Dates of death are like a variant of the calendar. Materialization of loss is like a way of patriotic education" (Oushakine 2009: 6). Here, "the formation of a therapeutic context - that is, the task of overcoming trauma - is replaced by attempts to relive (someone else's) loss again and again, to make it part of everyday life, to build a network of unifying rituals and practices around it" (ibid.: 7). In any case, the activation of someone else's trauma occurs due to a common narrative basis, which allows not only to pronounce the traumatic experience in the same way, but also to interpret it in the same way by using a common basic structure that sets the trajectory of thought along the main reference points fixed in linguistic, and therefore semantic, clichés. A certain set of these clichés, arranged in a certain order, gives the narrator the opportunity to describe the trauma in a certain way, using maximum emotional economy, but at the same time to express an attitude to the described experience, to embed it in a certain system of values. For example, people embed trauma narrative in a medical narrative 'pattern' by describing trauma as pain, in a legal (or ethical) 'pattern' by describing it as a crime, in an economic 'pattern' by describing it as a loss, etc. This 'pattern' could be called a descriptive bolvanka. We are not talking here about a structuralist search for a single basis, but in terms of borrowing, and not of transfer. ${ }^{2}$

The phenomenon of bolvanka originates from the Soviet period where it played an important role in Russian everyday life. The word derives from the Soviet bureaucratic practice and means a pre-prepared form of an official document (blank, template, form), where only specific data (e.g., personal information such as the name or time and place) can be changed. Etymologically, bolvanka comes from the Russian colloquial word bolvan ('dummy'), which originally meant 'idol, graven image', but received a negative connotation with a semantic emphasis on stupidity and passivity. From a positive side, bolvanka enables people to fulfil formal documents with the least emotional strain and loss of time and effort. However, its use is almost compulsory: not using the bolvanka template leads to an incorrectly filled document, which, as a result, will not be accepted.

In the case of a traumatic narrative, bolvanka seems to be an appropriate term for indicating a set of formal clichés, speech patterns, and narrative scenarios for constructing a story about trauma. Such a descriptive bolvanka is quite often used in traumatic discourse, allowing the speaker to talk about the trauma with the least emotional cost, changing only their personal information 
or data about a specific time and place. The basis of the descriptive bolvanka is formed by rhetorical (or narrative) ${ }^{3}$ patterns, i.e., operational clichés of syntactic constructions. Operational units (templates) are brought together in the format of a descriptive bolvanka. Both non-specialists and specialists alike use it for forming, reinforcing, and understanding trauma narratives. The economical descriptive bolvanka dominates in the discourse of cultural memory, whereas the normative (legal/ethical) one is the leading model in the discourse of cultural trauma. These two are seldom seen as two interwoven aspects of the same phenomenon, which they in fact are. They build and maintain their own descriptive models although both of them deal with key moments of the past.

Since traumatic discourse focuses on negative, painful, alienated experience, its form and content are censored not only by society, but also by the speaker. Thus, traumatic discourse usually deals with latent knowledge. The grammar of meanings/senses/significances, which is built up according to the syntax of rhetorical templates - the descriptive bolvanka - is quite strict in keeping information and emotions about the trauma hidden. It assumes not only what has already been said but dictates also what will be said. The expectations of the discourse set by this grammar of meanings/senses/significances act as an imperative for the speaker. Besides, the descriptive bolvanka is reproduced over and over again in the process of multiple repetition of patterns, which further reinforces its power. It allows the discourse not to identify and vocalize the latent content, but rather to carefully conceal the individual characteristics of a personal traumatic experience.

Such iterations of the descriptive bolvanka allow it to exist as a norm at the level of everyday consciousness. In this sense, it is akin to the functioning of folklore plots; it combines templates that exist within traditions. However, while folklore includes well-known and collectively adhered rules, it also displays individual creativity and variation, which makes up the strength of folklore. Therefore, folklore studies could provide a novel angle to describe and deconstruct the way in which traumatic descriptive bolvankas function, revealing the inherent structure of the set rules and templates. This special issue dedicated to the description of traumatic experience and, more broadly, cultural traumatology and its discursive practices, seeks to address the links between the collective and the individual, the theoretical and the material, and finally, the topographical aspects of trauma.

Folklore is transmitted from a person to a person; narratives of trauma spread and reproduce in a similar way. They are characterized by the total involvement of all members of a cultural community in the traumatic discourse. Such descriptive bolvankas also involve the stratification of society according to the participants in the trauma model: the (conditional) perpetrator (Arendt 
1964) or (conditional) victim (Peraica 2009). In this act of stratification, state institutions function as subjects that are indistinguishable from individual subjects. The total involvement of cultural subjects in a trauma-related discourse implies a massive interest in concealing the traumatic experience, and if we take into account that the conditional perpetrator usually represents the numerical majority of subjects in society and includes collective subjects such as state institutions or the state, the interest in concealing trauma is indeed almost total (see an overview of the 1977 Moncloa Pacts in Spain in Encarnación 2014, of the conspiracy of silence in the post-war FRG in Di Napoli 1982, etc.). The practice of silencing the public consensus may seem like a way to transfer trauma to a state of sacrifice, or as brokers put it, find a way to "fix losses", but in fact it is just the opposite: its aim is to freeze guilt/resentment/ responsibility, which in turn carries through one or several generations and causes an intergenerational gap, a cultural misunderstanding, a cold civil war (Encarnación 2014) or similar.

The total protection of one's "shameful" common past by culture is akin to the protection of one's criminal past by an individual criminal. The descriptive bolvanka allows everybody to highlight those features of the past that make the shameful elements invisible. It is based on the nostalgic tendencies of a culture (Boym 2002; Davis 1979; Wilson 2005; etc.), which form a system of values, and therefore a certain system of discursive expectations, rhetorical patterns, and a grammar of meanings/senses/significances. However, the nostalgic tendencies of selective memory actually look like the disintegration and degradation of memory in old age. The descriptive bolvanka and the grammar of meanings actually constructs the form of memory and interpretation about the not-yethappened, i.e., about the future. At the same time, the descriptive bolvanka also forms a "memory" of the traumatic experience in victims experiencing post-traumatic disorders. Since it tends to conceal rather than disclose, it is possible to talk about the latent (alienated) past with the help of clichés and/or (physical, material) markers. We can thus ask: Is there a common (universal) language for speaking about trauma? Can we adequately speak in one language about the traumatic experiences of the Chechens, Tatars, Germans, Russians, Jews, Latvians, and Estonians? Is the discourse of guilt appropriate? Or should it be about recognition?

From the point of view of absolute truth, a person carries the fullness of truth, otherwise he/she is a liar. It is impossible to leave half the truth at home and flaunt the streets with a convenient one. However, from the individual, pragmatic aspect this is exactly what happens when using the descriptive bolvanka. In contrast to ethical concepts, the theory of post-truth focuses on pragmatics (Keyes 2004; d'Ancona 2017; McIntyre 2018). It is necessary to judge the state 
and society from the point of view of absolute truth and people as members of these absolute institutions, rather than seeing a man as an individual, independent creature. In this sense, ethics presupposes that a person should act as if he is going to be judged from the point of view of absolute truth.

The laws of the state may be in conflict with the principles of absolute truth, and the legal institutions operating within the framework of state laws may also be untrue from the point of view of absolute truth. Classical political philosophy does not suggest such an option, but everyday practice shows a constant repetition of such a situation. What about those who deliberately separate laws from the absolute truth? How should responsibility be built in this case? Is the level of responsibility the same for all participants? Is the responsibility of Hitler and his supporting majority equal? Is the responsibility of the source of power equal to that of the instance of power inscribed in the collective pragmatic system of the exercise of untruth?

\section{EMBRACING THEORIES AND PRACTICES OF TRAUMA STUDIES: INTRODUCTION TO THE ARTICLES}

These and other questions were the focus of the international symposium under the heading "Between individual and collective cultural trauma", held at the Estonian Literary Museum on 12-13 March 2020. Some more prominent studies presented at this event are included in this special issue. The ten individual articles in this special issue address, firstly, the disciplinary transfer from a unified, universal approach to specific theories, cultural contexts, applications, and cases. Our aim is to maintain that the notion of trauma is diverse, and its diversity needs to be acknowledged and reflected also in the theory that explains and describes it. Secondly, the theoretical accounts are combined with practical, experimental, and materialized approaches to the phenomenon in many contributions to this issue. Thirdly, we felt that the topography of trauma needs far more attention than it has received until now, and this is what the authors of this special issue have kept in mind in their studies. In our view, the topography of trauma is tied tightly to the first point made here, namely that the generalized and universal ideas need to be seen as applicable to specific cases with their own material, topographical, and ideological aspects.

Drawing on the writings of Baudrillard and Derrida, Sergey Troitskiy seeks to identify the main features characterizing the functioning of trauma as a cultural mechanism within the framework of victim order and economy. He shows the transmission of an individual trauma into a collective one as a product of the construction of linguistic and cultural clichés (Oushakine 2009) or the 
descriptive bolvankas described above. He argues that the current trauma concept was woven into the cultural fabric of society only in the twentieth century, endowed with a strong collective and topographic meaning. It is closely connected to other aspects of a society, such as politics and economy, and suggests a new term - victim economy - to apply for such present-day political-economic interpretation of loss. This term, as he contends, incorporates important focus points of understanding trauma - political economy, and Baudrillard's description of contemporary reality of the victim society.

Dilemmas of forgetting and remembering arise with traumatic experiences. Selective memory of the trauma is conditioned by the visibility of events, but also impacted by social norms, normalized violence, and perceptions of atrocity, as illustrated in the study by Maya Camargo-Vemuri. Presenting a case study of sexual violence during the genocide, the author stresses the necessity to remember atrocities in as detailed and accurate manner as possible. Certain elements of narratives that are silenced because they trigger emotions of discomfort, pain, fear, anxiety, and even shame or guilt can carry a decisive role in the healing process. Furthermore, concealing trauma leads to the creation of a false history, which omits variables which may be a key to understanding larger processes and phenomena.

Another article that aims at deconstructing central notions in trauma studies is the one by Kseniya Kapelchuk. It rides on the third wave of memory studies, more specifically, on the theory put forth by Aleida Assmann. The critique to Assmann's trauma theory follows two lines of discourse: the level of facts and the level of value, as Kapelchuk argues. Departing from and building on Assmann's theory, the author shows the benefits of viewing these two levels separately in order to dissect the phenomenon more effectively and get closer to understanding trauma. Moreover, she points at the circular argument hidden in Assmann's responses to the critique. On the one hand, Assmann suggests that the changing perception of the painful past is brought about by the fall of the modern time regime, but on the other, she claims that the very establishment of the new time regime is explained as an effect of these painful events. This kind of arguing shows the vulnerability of the theory. Kapelchuk seeks to find solutions for this problem and recommends that the fundamental discussion about trauma discourse should tease apart the ontological and ethical levels of reasoning, and also address the value of such notions as ethical turn, human rights, and biopolitics.

The article by Tiiu Jaago underlines the importance of contextual folkloric reading of the life story texts, the meaning and narrator's focus of which change from generation to generation. When the traumatic memories referred to by Camargo-Vemuri follow the theoretical (and more conventional) understand- 
ing of how trauma is vocalized in a life story, the Estonian examples present a slightly different case. Here we can see how combining biographical analysis with the concept of trauma helps to understand the cultural connectivity of trauma expression. The article further elucidates the relationship between individual and cultural trauma, stating that these phenomena have a special relationship of parallel co-existence and occasional intertwinement (e.g., when the narrator links his or her story with some publicly mediated narrative; see also Jaago 2018). The cultural context in which the same (family) trauma is narrated changes over time, and so do the elements that are stressed and the interpretations of one's and other's actions, but this in turn offers new entry points into negotiating, defining, and understanding traumatic experiences of the past.

Authors in this issue address the material aspect of trauma. In her timely article, Tuulikki Kurki proposes an integrative approach to trauma narratives, which takes into account the narrative and non-narrative elements of trauma. Displaying data from border and mobility related interviews and artwork, Kurki formulates the notion of materialized trauma narrative. This novel, interdisciplinary approach aims to bring together the narrative and non-narrative knowledge of traumatic experiences that is embodied in a material object, for example, something carried along while crossing borders. These objects may hold a healing power, which lines this article up side by side with other practical, experience- and function-based contributions to trauma studies published in this special issue.

Humour and trauma often go hand in hand. Catastrophes, wars, and political upheavals bring along more or less tasteless jokes that aim to make sense of the situation (Laineste \& Lääne 2015; Stokker 1991, 1997). Humour can also cause or escalate traumatic experiences, as humour scandals of the last twenty years have proved (Kuipers 2008). In some cases, humour as a way to protest and fight inequality has been recorded (Sørensen 2015; 't Hart 2007, 2016). In any case, as functional as humour may seem, its functionality is unpredictable and thus its relationship with trauma can be equally both beneficial and detrimental. Alyona Ivanova in her article for this issue addresses the many connections between humour and trauma in hospital clowning, using interview data from practitioners. The study explores how not only the trauma of the patient, but also that of the clown meet in the hospital settings and lead to healing of the two sides involved, but ideally also the modern society that sets its context. On a theoretical level, this offers a highly valuable insight into the two concepts that stand so close yet so far apart. The paper carries, however, a very practical implication in addition to that: namely, it shows the steps to the healing potential of humour in the case of varied, complex traumas. 
Another practice-driven article about trauma is the one by Liat Steir-Livny, who analyses the ways of representing one trauma for two different audiences. The Zionist film Adamah (1948) and its remake, Tomorrow Is a Wonderful Day (1949), use the same footage to create two different narratives of the path of a Holocaust survivor in the Land of Israel. The author describes a recently recovered earliest version of the film, Adamah, which was initially dismissed on the basis of its too specific, "not fit for Hollywood" kind of approach to history and trauma. The second attempt was considered an international success. These two versions might mark the switch of narratives about the Holocaust and the building of the Israeli state. The original movie Adamah - the Eretz-Israeli version - stresses the importance of the community and the land, whereas the American edit of the same footage - Tomorrow Is a Wonderful Day - highlights the role of the individual who wants to realize his dream. It raises a question about the subjectivity-objectivity of the interpretations of trauma and points out that these are always conditioned by the needs of the subject, the needs of the audience, and the context of the times. This article offers another practical approach to understanding and analysing trauma narratives through bringing forth new, unique data.

The development of trauma theory has evidenced loud and detailed discussions of terminology and approaches; however, this has left the practical implications of research largely in the shadows. This is a lacuna that the current special issue seeks to address, in addition to presenting specific examples related to (post)-Soviet contexts (apart from the article by Steir-Livny, which falls outside of this area). The contribution by Yulia V. Zevako is a good example of how to tie trauma theory with practice. It offers a description of an experiment of re-experiencing and negotiating a trauma of the past. Talking about a trauma within a society means bringing it to the fore, becoming aware of its various aspects, the multiple narratives connected to it. Of course, not everything related to a trauma can or will be brought forth with equal strength or effect, which makes this particular project an exemplary one as it tries to narrate the side of the victim, the perpetrator, and the surrounding people and society all at once. The author describes the process of forming an individual affiliate memory of the era of political repression through an interactive exhibition of the complicated historical period meant for adolescents. This is a generation that has no direct connection or experience with that trauma; however, they are given an opportunity to relive the times and emotions of their grandparents when visiting and discussing the authentic space and artifacts of that era. Repeating history in a controlled setting results in the humanization of history, as adolescents take on emotional roles (as victims, relatives of victims, executioners, bystanders). 
It helps to begin to rethink and get rid of the "narrative of redemption" which prevents the understanding of the catastrophic past.

During the discussion held at the colloquium "Between individual and collective trauma", we evidenced that the location of trauma matters: from the way it is experienced to the way it can be described. The Eastern European context provides a promising arena to point at the specifically post-socialist elements in trauma-related discussions in society. A case study of the importance of martyrdom in the context of the design of collective trauma leads us closer to understanding the elements that condition the reactions to a trauma. Daniil Anikin, in his article about (post)-Soviet martyrdom-related myths, stresses that in such a traumatized society, the ubiquitous myth transforms the protagonist into a victimized hero, a suffering martyr. Following a detailed analysis of political and social developments in the image of the martyr, the author concludes that martyrological thinking is a mechanism for maintaining historical memory and collective identity, and as such it functions as an important element of trauma-related discourse. This approach presents a region-specific picture of processing trauma, underlining one of the main aims of this special volume, namely, to bring into focus the Eastern European and former Soviet-bloc-related context to trauma studies. The status of the martyr, for example, which was transposed from the dynastic affiliation to the simple worker or peasant, is something that is relevant to other post-Soviet countries as well. Similarly, the problematic position of such narratives in the present-day (political) discourse makes their use in the symbolic policy of the state almost impossible not only in Russia but also elsewhere in the area.

Uldis Krēsliṇš investigates a concrete, topographically specific case of publishing the card index of the Latvian Committee for State Security (KGB) of the Latvian Soviet Socialist Republic (Latvian SSR) after this Baltic republic had regained independence. The publication of the card index files was hoped to foster openness and justice; however, the author contends in conclusion that the expected results have not been achieved, neither in terms of historical truth, nor public reconciliation. The reasons for that are manifold: the uncertainty of the position of the political authority, the fragmented society and historical memory, and the place of trauma discourse in the preceding and consequent discussions surrounding the card files. The author also argues that the trauma of this historical experience in society's collective memory is not yet fully conscious, and this suggests yet another reason why the publication of the files was met with national polemics and heated public discussions.

The study of trauma is clearly interdisciplinary, as is also reflected in the articles chosen for this special issue. Different accents can be placed on topics 
inside trauma studies, for example, memory studies provide a disciplinary background for the articles by Kapelchuk, Zevako, and Steir-Livny; Ivanova's approach stems from the discipline of psychology; Anikin bases his article on theories of secular theology, while Troitskiy ventures into the study of cultural economy, and Kurki, herself a folklorist, lists research on material culture and multidisciplinary research into borders and mobility as her inspiration for writing this article.

The intersections of the three main focal points - universal/specific, theoretical/ material and topographical - intertwine: for example, in her article, Zevako puts a strong impact on the topographical aspect of coming to terms with trauma. In her museum experiment, the subjects came into contact with the authentic space of the traumatic times and negotiated their understanding of it precisely through physical space. Troitskiy stresses the importance of the topographical aspect of trauma, underlining that traumatic toponyms - Katyn, Auschwitz, Majdanek - often carry more concreteness (and thus more meaning for society) than temporal markers. Such layered, insightful interpretations are made possible by the open-mindedness and interdisciplinary interest of our authors.

Contemporary humanitarian science is oriented at the object of research. This makes it possible to ignore the boundaries of scientific disciplines and borrow methodology and instruments. The consequent research results in cross-disciplinary restrictions and boundaries, allowing for powerful generalizations and novel insights. Interdisciplinary practices may blur or even erase the boundaries between memory, cultural, literary, and trauma studies; however, each of these approaches carries a unique focus that should not be overlooked but rather seen as a strength and contribution to the overall picture of understanding trauma.

\section{ACKNOWLEDGEMENTS}

The symposium as well as the articles materialized as part of the research project No. 18-011-00570A with financial support from the RFBR. Neither the symposium nor this special issue could have materialized without the active participation and comprehensive assistance of Natalia Artemenko, a specialist in phenomenology and cultural trauma (see Artemenko 2018; 2019; 2020). The editors of the special issue express their sincere gratitude to her and hopes for further cooperation. The special issue is supported by the Centre of Excellence in Estonian Studies (CEES, TK-145) and ASTRA project of the Department of Folkloristics of the Estonian Literary Museum (through the European Regional Development Fund) and is related to research project EKM 8-2/20/3 (Estonian 
Research Council). Within the Centre of Excellence in Estonian Studies, its focus represents the interests of the working groups of the Studies of Contemporary Culture (incl. the media), Migration and Diaspora Studies, and Life Writing Studies.

\section{NOTES}

1 Ernst Kantorovicz (1957) showed these differences most accurately on the example of two bodies of the king, where the political body complements the physical one. The example of the royal body is most significant, since the king is removed from the system (Agamben 1998 [1995]: 57-62), although the political body was probably present in the subjects as well. When dealing with the reality of political death, psychotherapy is powerless (unlike physical death).

${ }^{2}$ Differences between borrowing and transfer were shown on the example of culture communication (Espagne 1999; Espagne \& Werner 1988). It seems correct to use the term "transfer" in the case where the subject is not culture but a person.

3 In this case, we can ignore the difference between "narrative" and "rhetorical", since we are talking about the operational side of the act itself.

\section{REFERENCES}

Adams, Jenni \& Vice, Sue 2013. Introduction. In: Jenni Adams \& Sue Vice (eds.) Representing Perpetrators in Holocaust Literature and Film. London \& Portland, OR: Vallentine Mitchell, pp. 1-12.

Agamben, Giorgio 1998 [1995]. Homo Sacer: Sovereign Power and Bare Life. Stanford, CA: Stanford University Press.

Arendt, Hannah 1964. Eichmann in Jerusalem: A Report on the Banality of Evil. New York: The Viking Press.

Artemenko, Natalia 2018. Vremia, pamiat', travma: mezhdu bytiem i nebytiem. [Time, Memory, Trauma: Between Being and Nonbeing.] Studia Culturae, Vol. 2, No. 36, pp. 124-136. Available at http://iculture.spb.ru/index.php/stucult/article/ view/1002/932, last accessed on 14 July 2021.

Artemenko, Natalia 2019. Ustnaia istoriia i problema dostupa k travmaticheskomu opytu. [Oral History and the Problem of "Access" to Traumatic Experience.] Studia Culturae, Vol. 2, No. 40, pp. 128-138. Available at http://iculture.spb.ru/index. $\mathrm{php} / \mathrm{stucult} /$ article/view/1129/1000, last accessed on 14 July 2021.

Artemenko, Natalia 2020. Ustnaia istoriia, praktiki pamiatstvovaniia i problema "dostupa" k travmaticheskomu opytu. [Oral History, Remembering Practices and the Problem of "Access" to the Traumatic Experience.] Corpus Mundi, Vol. 1, No. 4, pp. 14-33. DOI: $10.46539 / \mathrm{cmj} . v 1 i 4.30$. 
Assmann, Alleida 2016 [2006]. Shadows of Trauma: Memory and the Politics of Postwar Identity. Transl. by S. Clift. New York: Fordham University Press.

Balaev, Michelle (ed.) 2014. Contemporary Approaches in Literary Trauma Theory. Basingstoke: Palgrave Macmillan.

Bennett, Jill \& Kennedy, Rosanne 2003. Introduction. In: Jill Bennett \& Rosanne Kennedy (eds.) World Memory: Personal Trajectories in Global Time. New York: Palgrave Macmillan, pp. 1-15.

Boym, Svetlana 2002. The Future of Nostalgia. New York: Basic Books.

Caruth, Cathy 1995a. Introduction: Trauma and Experience. In: Cathy Caruth (ed.) Trauma: Explorations in Memory. Baltimore, MD \& London: The Johns Hopkins University Press, pp. 3-12.

Caruth, Cathy 1995b. Introduction: Recapturing the Past. In: Cathy Caruth (ed.) Trauma: Explorations in Memory. Baltimore, MD \& London: The Johns Hopkins University Press, pp. 151-57.

Caruth, Cathy 1996. Unclaimed Experience: Trauma, Narrative, and History. Baltimore, MD \& London: The Johns Hopkins University Press.

Craps, Stef \& Bond, Lucy 2020. Trauma. The New Critical Idiom. New York \& London: Routledge.

Cwalina, Wojciech \& Falkowski, Andrzej 2008. Constructivist Mind: False Memory, Freedom, and Democracy. Journal of Political Marketing, Vol. 7, No. 3/4, pp. 239255. http://dx.doi.org/10.1080/15377850802008319.

d'Ancona, Matthew 2017. Post-Truth: The New War on Truth and How to Fight Back. London: Ebury Press.

Davis, Colin \& Meretoja, Hanna 2020. Introduction to Literary Trauma Studies. In: Colin Davis \& Hanna Meretoja (eds.) The Routledge Companion to Literature and Trauma. New York \& London: Routledge, pp. 1-8.

Davis, Fred 1979. Yearning for Yesterday: A Sociology of Nostalgia. New York: The Free Press.

Di Napoli, Thomas 1982. Reception of the Holocaust in the German Democratic Republic: A Philatelic Commentary. Jewish Social Studies, Vol. 44, No. 3/4, pp. 255-270. Available at https://www.jstor.org/stable/4467185, last accessed on 14 July 2021.

Douglas, Kate 2010. Contesting Childhood: Autobiography, Trauma, and Memory. New Brunswick, NJ \& London: Rutgers University Press.

Douglas, Kate \& Whitlock, Gillian \& Stumm, Bettina 2008. Editorial: Trauma in the Twenty-First Century. Life Writing, Vol. 5, No 1, pp. 1-8. https://doi. org/10.1080/14484520801902308.

Encarnación, Omar G. 2014. Democracy Without Justice in Spain: The Politics of Forgetting. Philadelphia, PA: University of Pennsylvania Press.

Espagne, Michele 1999. Les transferts culturels franco-allemands. Paris: PUF.

Espagne, Michel \& Werner, Michael 1988. Transferts. Les relations interculturelles dans l'espace franco-allemand. Textes réunis et présentés par M. Espagne et M. Werner. Paris: Editions Recherche sur les Civilisations.

Fassin, Didier \& Rechtman, Richard 2009. The Empire of Trauma: An Inquiry into the Condition of Victimhood. Princeton \& Oxford: Princeton University Press. 
Felman, Shoshana \& Laub, Dori 1992. Testimony. Crises of Witnessing in Literature, Psychoanalysis, and History. New York: Routledge.

Gheith, Jehanne M. 2007. 'I Never Talked': Enforced Silence, Non-Narrative Memory, and the Gulag. Mortality, Vol 12, No 2, pp. 159-175. https://doi. org/10.1080/13576270701255149.

Gilmore, Leigh 2001. The Limits of Autobiography: Trauma and Testimony. Ithaca, NY \& London: Cornell University Press.

Gilmore, Leigh 2008. What Do We Teach When We Teach Trauma? In: Miriam Fuchs \& Craig Howes (eds.) Teaching Life Writing Texts. New York: Modern Language Association of America, pp. 367-373.

Gilmore, Leigh 2017. Tainted Witness: Why We Doubt What Women Say about Their Lives. New York: Columbia University Press.

Halligan, Sarah L. \& Clark, David M. \& Ehlers, Anke 2002. Cognitive Processing, Memory, and the Development of PTSD Symptoms: Two Experimental Analogue Studies. Journal of Behavior Therapy and Experimental Psychiatry, Vol. 33, No. 2, pp. 73-89. http://dx.doi.org/10.1016/S0005-7916(02)00014-9.

Herman, Judith Lewis 1992. Trauma and Recovery: The Aftermath of Violence - from Domestic Abuse to Political Terror. New York: Basic Books.

Hodgkin, Katharine \& Radstone, Susannah 2003. Remembering Suffering: Trauma and History. In: Katharine Hodgkin and Susannah Radstone (eds.) Contested Pasts: The Politics of Memory. London \& New York: Routledge, pp. 97-103.

Huyssen, Andreas 2003. Present Pasts: Urban Palimpsests and the Politics of Memory. Stanford, CA: Stanford University Press.

Jaago, Tiiu 2018. Trauma ja elulood. [Trauma and Life Stories.] Mäetagused, Vol. 71, pp. 111-142. https://doi.org/10.7592/MT2018.71.jaago2.

Jelinek, Lena \& Hottenrott, Birgit \& Randjbar, Sarah \& Peters, Maarten J. \& Moritz, Steffen 2009. Visual False Memories in Post-Traumatic Stress Disorder (PTSD). Journal of Behavior Therapy and Experimental Psychiatry, Vol. 40, No. 2, pp. 374383. http://dx.doi.org/10.1016/j.jbtep.2009.02.003.

Jensen, Meg 2019. The Art and Science of Trauma and the Autobiographical: Negotiated Truths. Basingstoke: Palgrave Macmillan.

Kansteiner, Wulf 2004. Testing the Limits of Trauma: The Long-Term Psychological Effects of the Holocaust on Individuals and Collectives. History of the Human Sciences, Vol. 17, No. 2-3, pp. 97-123. http://dx.doi.org/10.1177/0952695104047299. Kantorowicz, Ernst H. 1957. The King's Two Bodies: A Study in Mediaeval Political Theology. Princeton: Princeton University Press.

Keyes, Ralph 2004. The Post-Truth Era: Dishonesty and Deception in Contemporary Life. New York: St. Martin's Press.

Kuipers, Giselinde 2008. The Muhammad Cartoon Controversy and the Globalization of Humor. Humor: International Journal of Humor Research, Vol. 21, No. 1, pp. 7-11.

Kurvet-Käosaar, Leena 2020. Trauma and Life Writing. In: Colin Davis \& Hanna Meretoja (eds.) The Routledge Companion to Literature and Trauma. New York \& London: Routledge, pp. 305-314.

LaCapra, Dominick 2000. Writing History, Writing Trauma. Baltimore, MD: The Johns Hopkins University Press. 
Laineste, Liisi \& Lääne, Margus 2015. Images of the Enemy from Both Sides of the Front: The Case of Estonia (1942-1944). In: Dagnosław Demski \& Liisi Laineste \& Kamila Baraniecka-Olszewska (eds.) War Matters: Constructing the Image of the Other (1930-1950). Budapest: L'Harmattan, pp. 222-243.

Leys, Ruth 2000. Trauma: A Genealogy. Chicago \& London: The University of Chicago Press.

Luckhurst, Roger 2008. The Trauma Question. New York: Routledge.

McIntyre, Lee 2018. Post-Truth. London \& Cambridge: MIT Press.

Meretoja, Hanna 2020. Philosophies of Trauma. In: Colin Davis \& Hanna Meretoja (eds.) The Routledge Companion to Literature and Trauma. New York \& London: Routledge, pp. 23-35. Available at https://tandfbis.s3-us-west-2.amazonaws. com/rt-files/docs/Open+Access+Chapters/9781351025225_oachapter2.pdf, last accessed on 15 July 2021.

Merridale, Catherine 2010. Soviet Memories: Patriotism and Trauma. In: Susannah Radstone and Bill Schwarz (eds.) Memory: Histories, Theories, Debates. New York: Fordham University Press, pp. 376-389.

Miller, Nancy K. \& Tougaw, Jason 2002. Introduction: Extremities. In: Nancy K. Miller \& Jason Tougaw (eds.) Extremities: Trauma, Testimony and Community. Urbana, IL \& Chicago: University of Illinois Press, pp. 1-21.

Oushakine 2009 = Ushakin, Sergei. "Nam etoi bol'iu dyshat"? O travme, pamiati i soobshchestvakh. ["Should We Breathe This Pain"? On Trauma, Memory, and Communities.] In: Sergei Ushakin \& Elena Trubina (eds.) Travma: Punkty. [Trauma: Points.] Moscow: Novoe literaturnoe obozrenie, pp. 5-41. Available at https://scholar.princeton.edu/sites/default/files/oushakine/files/190-2039942.pdf, last accessed on 5 July 2021.

Paperno, Irina 2009. Stories of the Soviet Experience: Memoirs, Diaries, Dreams. Ithaca \& London: Cornell University Press.

Pederson, Joshua 2018. Trauma and Narrative. In: Roger Kurtz (ed.) Trauma and Literature. Cambridge: Cambridge University Press, pp. 97-109. https://doi. org/10.1017/9781316817155.008.

Pederson, Joshua 2020. Cognitive Approaches to Trauma and Literature. In: Colin Davis \& Hanna Meretoja (eds.) The Routledge Companion to Literature and Trauma. New York \& London: Routledge, pp. 220-229.

Peraica, Ana (ed.) 2009. Victims Symptom (PTSD and Culture). Amsterdam: Institute of Network Cultures.

Schaffer, Kay \& Smith, Sidonie 2004. Human Rights and Narrated Lives: The Ethics of Recognition. New York: Palgrave Macmillan.

Seltzer, Mark 1997. Wound Culture: Trauma in the Pathological Public Sphere. October, Vol. 80, pp. 3-26. https://doi.org/10.2307/778805.

Sørensen, Majken Jul 2015. Humorous Political Stunts: Nonviolent Public Challenges to Power. Sparsnäs, Sweden: Irene Publishing.

Stokker, Kathleen 1991. Heil Hitler - God Save the King: Jokes and the Norwegian Resistance 1940-1945. Western Folklore, Vol. 50, No. 2, pp. 171-190. http://dx.doi. org/10.2307/1500046. 
Stokker, Kathleen 1997. Folklore Fights the Nazis: Humor in Occupied Norway, 19401945. Madison, WI: University of Wisconsin Press.

Sütterlin, Nicole A. 2019. Poetik der Wunde: Zur Entdeckung des Traumas in der Literatur der Romantik. Göttingen: Wallstein.

Sütterlin, Nicole A. 2020. History of Trauma Theory. In: Colin Davis \& Hanna Meretoja (eds.) The Routledge Companion to Literature and Trauma. London \& New York: Routledge, pp. 11-22.

't Hart, Marjolein 2007. Humour and Social Protest: An Introduction. International Review of Social History, Vol. 52, No. S15, pp. 1-20. http://dx.doi.org/10.1017/ S0020859007003094.

't Hart, Marjolein 2016. The Role of Humor in Protest Cultures. In: Kathrin Fahlenbrach \& Martin Klimke \& Joachim Scharloth (eds.) Protest Cultures: A Companion. New York \& Oxford: Berghahn Books, pp. 198-204.

Traverso, Antonio \& Broderick, Mick 2010. Interrogating Trauma: Towards a Critical Trauma Studies. Continuum: Journal of Media \& Cultural Studies, Vol. 24, No. 1, pp. 3-15. http://dx.doi.org/10.1080/10304310903461270.

Tumarkin, Maria M. 2011. The Long Life of Stalinism: Reflections on the Aftermath of Totalitarianism and Social Memory. Journal of Social History, Vol. 44, No. 4, pp. 1047-1061. http://dx.doi.org/10.1353/jsh.2011.0043.

Whitehead, Anne 2004. Trauma Fiction. Edinburgh: Edinburgh University Press.

Wilson, Janelle L. 2005. Nostalgia: Sanctuary of Meaning. Lewisburg, PA: Bucknell University Press.

Yaeger, Patricia 2002. Consuming Trauma; or, The Pleasures of Merely Circulating. In: Nancy K. Miller \& Jason Tougaw (eds.) Extremities: Trauma, Testimony and Community. Urbana, IL \& Chicago: University of Illinois Press, pp. 25-51.

Sergey Troitskiy is Senior Research Fellow (PhD) at the Herzen State Pedagogical University of Russia. His main research areas are theory of cultural exclusion and frontier zones, trauma and memory studies, methodology of cultural studies in perspectives of Russian philosophy.

sergtroy@yandex.ru

Leena Kurvet-Käosaar is Associate Professor of Cultural Theory $(\mathrm{PhD})$ at the University of Tartu, Estonia, and, together with Triinu Ojamaa, the leader of the research group on migration and diaspora studies of the Centre of Excellence in Estonian Studies. Her main research areas include life-writing studies, migration studies, personal narratives of Soviet deportations and the Gulag, and trauma studies.

leena.kurvet-kaosaar@ut.ee 
Liisi Laineste is Senior Research Fellow $(\mathrm{PhD})$ at the Department of Folkloristics of the Estonian Literary Museum and at the Centre of Excellence in Estonian Studies, Estonia. Her main research subject is folk humour and its different manifestations. She has published articles on ethnic humour, internet folklore, and caricatures. She has co-authored studies that deal with ethnic jokes and their globalization (2017; with A. Fiadotava) and online rumours (2017; with E. Kalmre); together with Sharon Lockyer she edited a special issue of HUMOR: International Journal of Humor Research (2019), dedicated to the work of Christie Davies, and an issue of Journal of Pragmatics on communication styles (2019).

liisi.laineste@folklore.ee 